\title{
An Uncommon Cause of Cholangitis and Cholecystitis
}

\author{
João Sebastião Lopes Dias Pinto Richard José Lopes Azevedo \\ António José Duarte Banhudo \\ Gastroenterology Department, Hospital Amato Lusitano, Unidade Local de Saúde de Castelo Branco, \\ Castelo Branco, Portugal
}

\section{Keywords}

Ascaris lumbricoides - Cholangitis - Endoscopic retrograde cholangiopancreatography · Endoscopic ultrasound

\section{Uma causa incomum de colangite e colecistite}

\section{Palavras Chave}

Ascaris lumbricoides · Colangite · Colangiopancreatografia retrógrada endoscópica $\cdot$ Ecoendoscopia

A 69-year-old rural male presented to the emergency department with a 6-day history of increasing right hypochondrium pain, jaundice, and choluria. The patient had no fever, chills, nausea, or vomiting.

On physical examination, he was jaundiced, afebrile, and hemodynamically stable, with right-upper quadrant abdominal pain but without abdominal tenderness. Blood tests revealed normal blood cell counts, mild elevation of C-reactive protein $(31.0 \mathrm{mg} / \mathrm{L})$, cholestasis (alkaline phosphatase $479 \mathrm{U} / \mathrm{L}, \gamma$-GT 1,111 U/L) and hyperbilirubinemia $(9.6 \mathrm{mg} / \mathrm{dL})$. Abdominal ultrasound revealed dilated intrahepatic biliary ducts and common bile duct, filled with echogenic material. The gallbladder presented consistent findings with acute cholecystitis (oedema and stratification

\section{KARGER}

E-Mail karger@karger.com www.karger.com/pjg (c) 2017 Sociedade Portuguesa de Gastrenterologia Published by S. Karger AG, Basel

Karger

Open access

This article is licensed under the Creative Commons AttributionNonCommercial-NoDerivatives 4.0 International License (CC BY NC-ND) (http://www.karger.com/Services/OpenAccessLicense). Usage and distribution for commercial purposes as well as any distribution of modified material requires written permission. of the gallbladder wall, lumen filled with echogenic millimetric particles compatible with microlithiasis). Subsequently, endoscopic ultrasound was performed and revealed inflamed (diffuse ductal wall oedema) and dilated common bile duct and cystic duct, both filled by an elongated and rounded structure with a double-tubular core (Fig. 1), and multiple enlarged hilar lymph nodes.

According to the diagnosis of cholangitis, an endoscopic retrograde cholangiopancreatography was performed. When reaching the duodenum, a squirming live worm was observed coming out of the papilla (Fig. 2). It was gently grasped using a rat-tooth forceps and pulled out by removing the duodenoscope and forceps together through the mouth (Fig. 3). Cholangiography showed no filling defects. The pathological examination was consistent with a specimen of Ascaris lumbricoides (Fig. 4) and a single dose of albendazole was administered. The patient had a complete clinical and analytical recovery and was discharged with a scheduled delayed laparoscopic cholecystectomy.

Ascariasis is the most prevalent helminthic infection in humans, above all in tropical countries with poor socioeconomic conditions. It is acquired through the ingestion of matured ova in contaminated water, raw vegetables, and food [1-3].

Once in the duodenum, eggs hatch and larvae are released, penetrating the mucosa and migrating through 


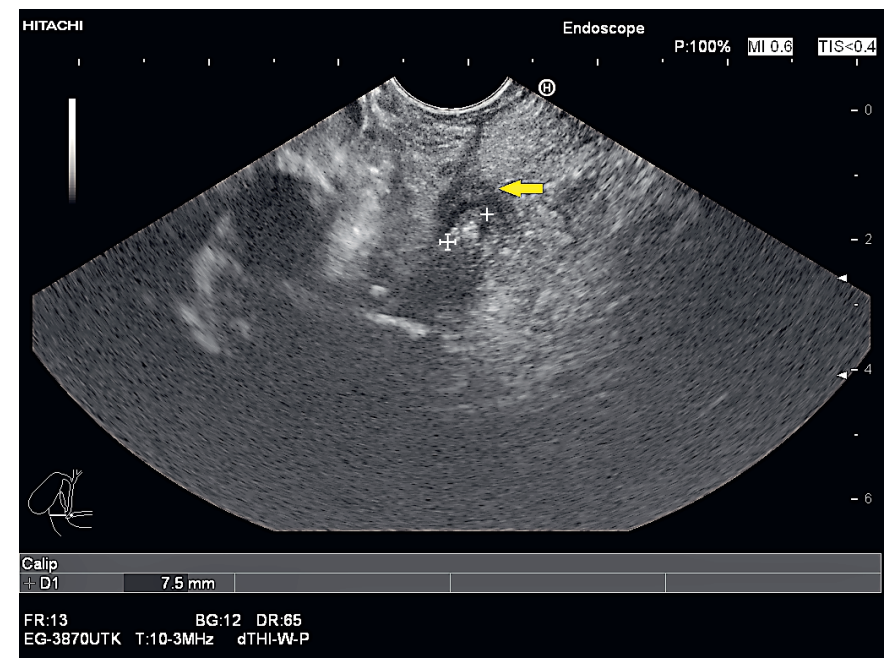

Fig. 1. Inflamed proximal common bile duct with oedematous wall (arrow) and filled by an elongated and rounded structure with a double-tubular core measuring $7.5 \mathrm{~mm}$ in diameter (between crosses).

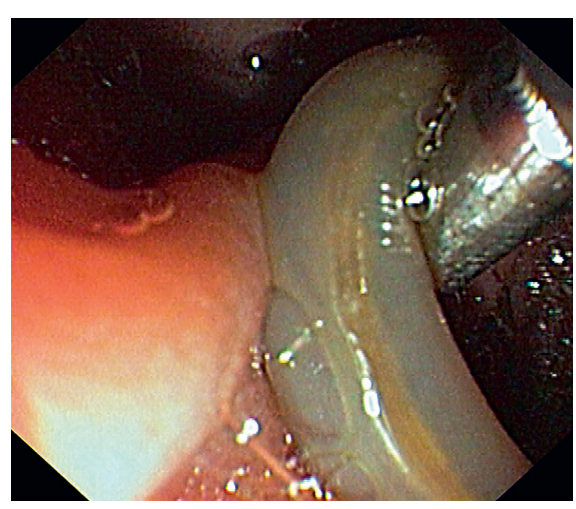

Fig. 2. Living worm coming out of the papilla.
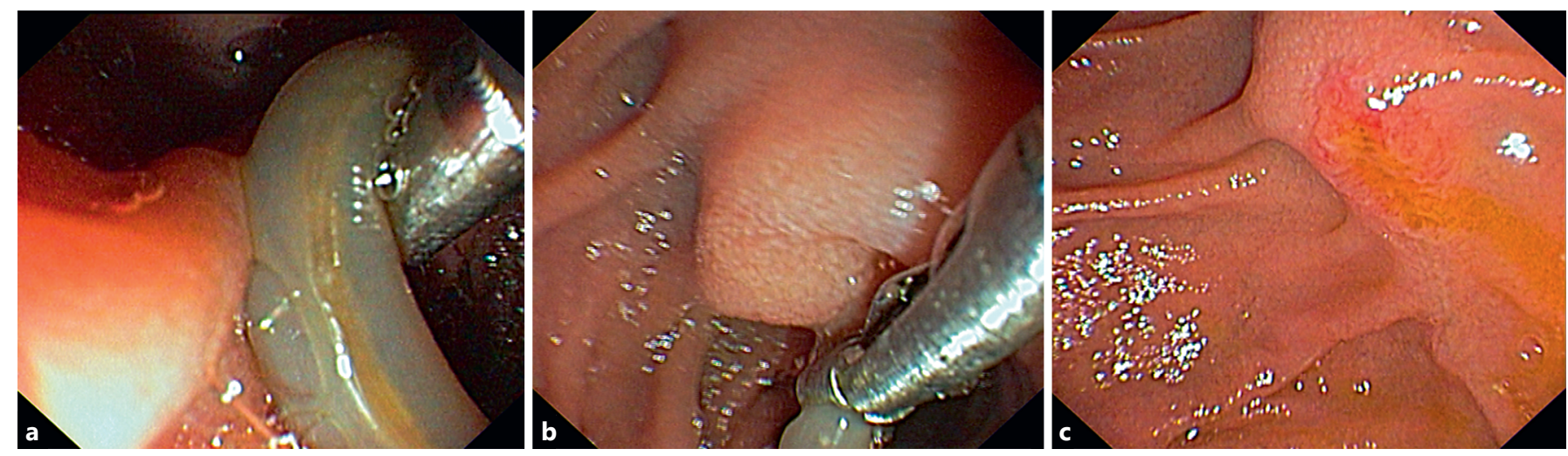

Fig. 3. Endoscopic removal of the parasite: detailed view of the body of the worm (a); endoscopic forceps grasping the worm (b); major papilla draining clear bile $(\mathbf{c})$.

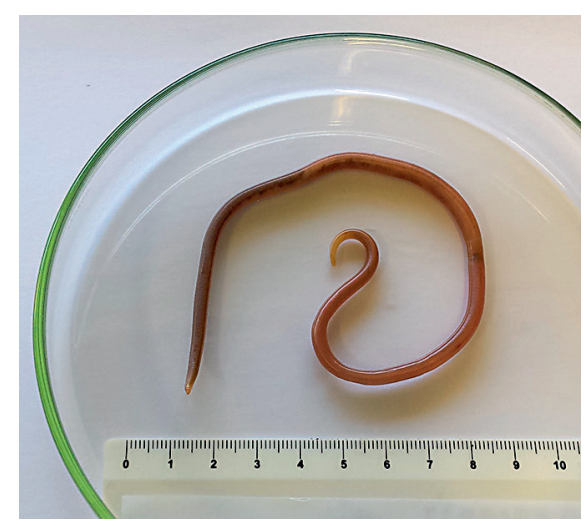

Fig. 4. Macroscopic evaluation of the Ascaris lumbricoides worm. the portal system to the pulmonary circulation. There, after moulting, they gain access to the alveolar space. Some will ascend the respiratory tree before being swallowed and reaching again the duodenum, where the final moulting to the adult state occurs [1,2]. Mature larvae inhabit the jejunum with a life span of 6-18 months, reaching up to $20-40 \mathrm{~cm}$ of length. Females can release $\sim 200,000$ eggs/day, excreted through the faeces. After $10-15$ days in the soil, an intermediate maturation step occurs before these eggs become infectious $[1,2]$.

Although the infestation is usually asymptomatic, some carriers develop clinical disease according to the organs strolled by the parasite throughout its life cycle: pneumo- 
nia, gastrointestinal occlusive symptoms, peritonitis, as well as pancreatic and hepatobiliary manifestations $[1,2]$.

The latter arise when worms enter the ampulla of Vater and have a wide range: cholangitis, cholecystitis, hepatic abscesses, strictures, and biliary sludge and stones [1-4].

We presented a case of acute cholecystitis and cholangitis related to the infestation by $A$. lumbricoides, which is nowadays an uncommon aetiology of biliary obstruction in European countries.

\section{Statement of Ethics}

The authors declare that no experiments were performed on humans or animals for this study and that no patient data appear in this article.

\section{Disclosure Statement}

The authors declare no conflicts of interest.

References

1 Singh D, Yang S, Cappell MS: Biliary ascariasis diagnosed and extracted by ERCP in the United States. ACG Case Rep J 2016;3:e188e189.

2 Das AK: Hepatic and biliary ascariasis. J Glob Infect Dis 2014;6:65-72.

3 Khuroo MS, Rather AA, Khuro NS, et al: Hepatobiliary and pancreatic ascariasis. World J Gastroenterol 2016;22:7507-7517.

4 Mansilla-Vivar R, Caballero ES, Dueñas CS, et al: Biliary ascariasis as etiology of recurrent abdominal pain. Endoscopy 2016;48(suppl 1):E196. 